\title{
Brand Storytelling of Wedding Marketplace
}

\author{
Nizar Alam Hamdani, Anggun Oktavia Herlianti
}

\begin{abstract}
Digital economy propels the service industry to integrate online and offline interactions between companies and its customers. This study was intended to describe the brand storytelling in wedding marketplace that has a special blog to share its customer's story. This study involved 135 respondents surveyed through online questionnaires. The result concluded that the brand storytelling has received an objectively good response. This indicated that the company must elucidate inviting storytelling with the intention of attracting customers' responses
\end{abstract}

\section{Keywords: Brand Storytelling; Wedding Marketplace}

\section{INTRODUCTION}

The development of e-commerce is currently marked by the emergence of many new startups in various industrial sectors (1)(2). One of the emerging and attention-grabbing startups is marketplace (3). Marketplace development is attracting service businesses to participate in marketing their services (4). This has stimulated dramatic change in the marketing practice within business players. The main alterations occur in the shift from textual marketing model into contextual model that requires marketers to create an emotional bond between the company and its customers (5). This emotional bond between consumers and brands can be created through personal and interesting communication (6). A product is not only distinguished by its physical difference, but the difference also lies in storytelling (7). The ability of brand storytelling of a marketplace company will have a long term effects (8). Companies not only introduce their products but they must also deliver the key messages relevant to their customer situation (9).

Brand storytelling is not a novelty in marketing (5). This concept has been implemented by wedding marketplace as an online wedding vendor community projected to inspire couples to find the best wedding vendors easily and quickly. Wedding marketplace not only displays services offered by vendors, but it also allows visitors to collect and share various stories, photos, wedding accessories on their social media (swa.co.id, akses 18 April 2019). Wedding marketplace provides a way out for finding the best wedding vendors. Wedding marketplace serves as a platform to browse a large and growing database of wedding vendors (10). In addition, wedding marketplace sell not only products or services, but also experiences offered from various narrative and contextual stories in the form of inspiring and creative photos from each vendor that can be reviewed by its customers. The inspirations from the customers can also be conveyed to the company through stories written on websites and on other social media (11).

Revised Manuscript Received on April 19, 2019.

Nizar Alam Hamdani,

Anggun Oktavia Herlianti,
Wedding marketplace in Indonesia has an annual progressive trend both in terms of budgeting, planning, preparation and other matters. The value of this marriagebased business continues to increase every year with more than US \$ 7 billion / year capital turnover. Indonesian wedding marketplace began to go into the digital world in the last few years (12). Table 1.2 about the Country Rank of the Wedding Marketplace Startup Company shows the reliability of wedding marketplace company startup. The report shows that Weddingku, at 4,684 position, is superior to other startups including Bridestory. It indicates that the public is more familiar with Weddingku than others.

Table 1. Country Rank Of Indonesia Wedding Marketplace Startup In 2019

\begin{tabular}{ll}
\hline Startup & Country Rank \\
\hline Weddingku & 4.684 \\
Bridestory & 6.142 \\
The Bride Dept & 12.533 \\
Rumah taaruf & 32.243 \\
DatangYa & 40.247 \\
\hline
\end{tabular}

Sources: Similiarweb.com, akses 18 April 2019

Weddingku and Bridestory are two established wedding marketplaces compared to other wedding marketplaces in Indonesia where there are thousands of wedding vendors who have joined a platform connecting wedding vendors and prospective brides (14). Continuous two-way interaction with brands is the main asset and success indicator in a technology-based business due to the fact that the interaction is a subjective response to a brand that involves consumers' cognitive and affective aspects. Brands will depend on repeated interactions with its users to generate additional revenue through advertising, licenses or subscriptions in addition to direct revenue from sales (15).

Storytelling activities in marketing and branding are different from storytelling in entertainment activities. There are certain distinctive dimensions in the branding perspective contributes to the storytelling activities carried out by the company (9). The storytelling in marketing activities carried out on the marketplace is expected to improve and increase the marketplace company value. Therefore, it is necessary to do research on the brand storytelling of wedding marketplace. The purpose of this study is to get an overview of the brand storytelling in wedding marketplace. 


\section{LITERATURE REVIEW}

Strategic brand management includes the design and implementation of marketing programs and activities to build, measure and manage brand equity (Keller, 2013:254) (17). Brand management is considered useful in utilizing the assets of an organization in order to generate added value from the investments that have been made into a brand (Keller, 2013:143). Brand management has been analyzed for more than 20 years by experts and they have come up with seven brand approaches presented in chronological order divided into three periods of time (Heding, Knudtzen, \& Bjerre, 2015:22).

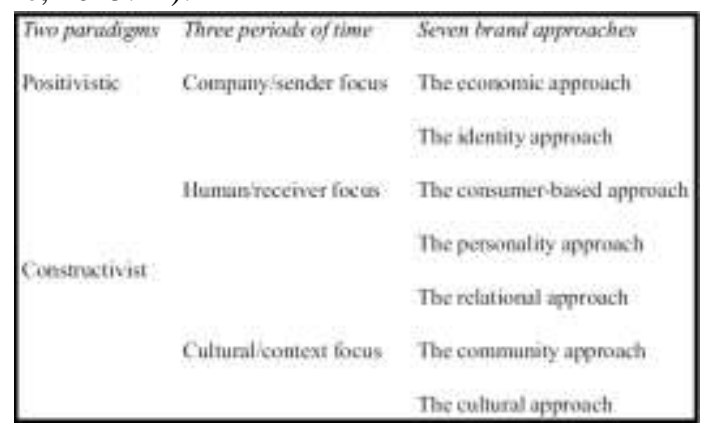

Fig. 1, Brand Management Approach Description

Based on Figure 1, there are two paradigms in brand management used from 1985 to 2006 i.e. positivistic and constructivist or natural interpretation paradigms. The positivistic paradigm entails a brand as a marketer idea that control the communication with customers. Brand equity is deemed to be made by marketers and brands are seen as lifeless relics in addition to company products to create a corporate image. Constructivist paradigms or natural interpretations reflect the nature of the brand and accept the brand equity value as a result of the interaction between marketers and consumers and is considered as a living entity and can develop over time (Hanby dalam Heding et al., 2015:21).

Figure 1 illustrates the 7 brand approaches for 3 periods of time. The following is a description of the brand approach from each period:

Period 1985-1992 (Company / Sender Focus). This period focuses on the company as the sender of brand communication and it is assumed that the brand belongs to the company and is communicated linearly from a company to its consumer. The focus on this period is the background of the first two approaches to brand management i.e. economic and identity approaches (Heding et al., 2015:22).

1) The economic approach. The economic approach focuses on the possibility of companies to manage brands through marketing mixed elements (product, placement, price and promotion) and how these factors can be manipulated to influence customer choices. Quantitative data became the main role in this period.

2) The Identity Approach. The Identity Approach focuses on whole corporate identity that can form a coherent brand communication message for all shareholders. Brand is also considered as an entity belonging to marketers who are responsible for creating the brand value. Brand integration at all levels of the organization is the key to the brand management.

Period 1993-1999 (Human/Receiver Focus)
1) The Consumer-Based Approach. In 1993 Kevin Lane Keller founded a new brand management approach. A brand is considered as a cognitive interpretation assuming that a strong brand holds strength, uniqueness and positive associations in its consumer minds. This approach considers consumers as the brand owners (Heding et al., 2015:24).

2) The Personality Approach. This approach claims that consumers have a tendency to characterize brands with human personalities so that brands are considered as human characters (Heding et al., 2015:24).

3) The Relational Approach. This approach considers the brand as a worthy partner and can expand the dialog-based approach-brand management approach as a reference in the personality approach (Heding et al., 2015:24).

Period 2000-2006 (Cultural/Context Focus)

1)The Community Approach. The community approach is based on anthropological research so that it is called the brand community. Brand value is created in communities where the brand functions as an important point of social interaction among consumers which in turn increasing the context of their social consumption towards the overall picture of brand management. This understanding has become a prerequisite for managing brands, especially after the internet has changed the market (Heding et al., 2015:25).

2) The Cultural Approach. Brands are seen as cultural relics and this approach give an idea of how to build an iconic brand. This approach explains what brands do for macro-level culture and how to embed brands in cultural strength so that they can be used strategically to build an iconic brand (Heding et al., 2015:25).

One of the approaches used in brand management in the third period is the consumer-based approach. Consumers have become an attractive main point in this approach and are considered as the brand owners. Brand value creation takes place by forming brand associations that occur in the consumers' mind so that understanding consumers becomes important in creating brand value. Consumers are analyzed theoretically by adopting cognitive psychology and information processing theories (Keller, 2013:85).

$$
\text { Brand Storytelling Drivers }
$$

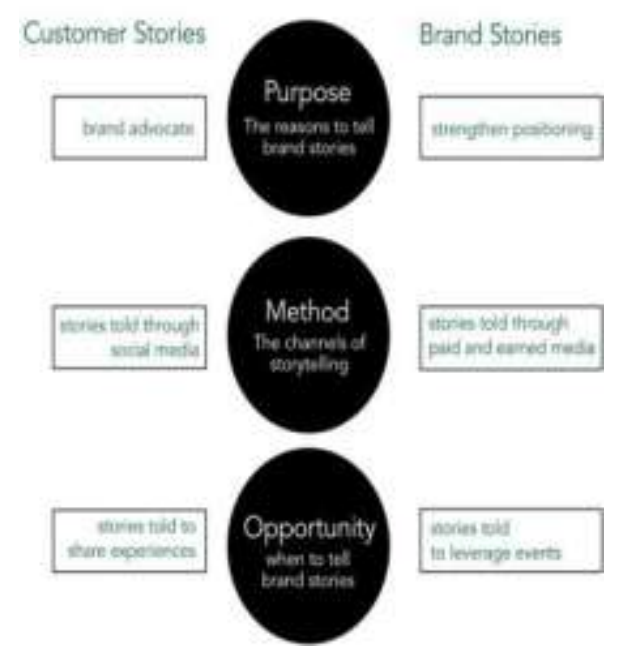

Fig. 2, Brand Storytelling drivers 
The most basic goals or reasons for brands to tell their stories are usually to create or strengthen brand positioning and competitive advantage. For customers, their motivation or purpose to tell the brand's story comes from the desire to share their ideas and experiences as fans of the brand's core goals. In other words, the strategic goals in the brand's story are based on resonance and relevance. Brands undoubtedly have many methods and media channels to tell their stories. The audience is now very fragmented and the method tell less about the media yet more about real involvement. Customers also have more methods available through social media channels in sharing company brand stories that mean that their brand stories are now shared experiences. Both brands and customers contribute to each other in a more tangible and meaningful way.

Storytelling is part of communication marketing. To build a brand from an online business, several marketing communication activities can be developed by marketers and non-marketers such as word-of-mouth (19). Brand storytelling is the ability to tell the brand aspects so as to form emotional relationships with stakeholders such as sales, public speakers, suppliers, distributors, and consumers who bring a message from a brand to others (5). There are three drivers for brand storytelling strategies, i.e.: 1) purposes, 2) methods, and 3) opportunities. These drivers work consistent with the story the customer tells and the story the brand tells to the customer.

Brand opportunities to tell stories are diverse and varied. On the one hand, brand storytelling creates product innovation and important events awareness. On the other hand, this creates a more difficult problem than a public relations disaster. Brands can be proactive or reactive in this case. For customers, the opportunity to tell stories on their own initiative is also driven by good or bad news about brand experience. Enlightened marketers now realize that they must provide a place to invite their customers to share their experiences and tell their stories. Brand storytelling will be an important component for building long-lasting connections with people who share the same thoughts. All legendary brands have legendary stories passed down from generation to generation. Strategies for creating interesting brand stories are driven by brand's goals, level of engagement, and ability to take advantage from various events and circumstances from customers' experiences.

\section{METHOD}

This study is descriptive in nature. The population was wedding marketplace visitors joined in wedding marketplace fanpage. Out of which, 135 respondents were used as the sample of the study. The data was collected through questionnaires. There are two sampling techniques used in this descriptive study i.e. probability sampling and accidental sampling techniques. Probability sampling was used to give an equal chance to the population to be taken as the sample. On the other hand, accidental simple random sampling was intended to take the sample in more convenient ways.

\section{RESULT AND DISCUSSION}

Use either SI (MKS) or CGS as primary units. (SI units are strongly encouraged.) English units may be used as secondary units (in parentheses). This applies to papers in data storage. For example, write " $15 \mathrm{~Gb} / \mathrm{cm}^{2}$ (100 Gb/in $\left.{ }^{2}\right)$." An exception is when English units are used as identifiers in trade, such as " $3 \frac{1}{2}$ in disk drive." Avoid combining SI and CGS units, such as current in amperes and magnetic field in oersteds. This often leads to confusion because equations do not balance dimensionally. If you must use mixed units, clearly state the units for each quantity in an equation. In general, Brand Storytelling variables consisting of Memorable, Recognizable, Inspiration, Influence, and Persuasion dimensions can be measured based on the scores obtained from the recapitulation of the variables. Table 2 about the Wedding Marketplace Website Visitor's Response to Brand Storytelling was obtained from the results of data processing from the questionnaires distributed to 135 Wedding Marketplace website visitors. The highest score was in the memorable dimension by $79.29 \%$. This is because the consumers considered brand experience as a result of memorable things; things that leave a good impression to the consumers. The lowest score was obtained from the influence dimension by $75.41 \%$. This is because consumers believed that the creation of brand storytelling was less influential to them.

Table 2. Website Bridestory Visitor Responses on Brand Experience

\begin{tabular}{lrlll}
\hline Dimensions & Scores & $\begin{array}{l}\text { Averag } \\
\text { e } \\
\text { Scores }\end{array}$ & $\begin{array}{l}\text { Ideal } \\
\text { Scores }\end{array}$ & $\%$ \\
\hline Influence & 3.563 & 712.60 & 945 & $\begin{array}{l}75.4 \\
1\end{array}$ \\
\hline Recognizable & 2.237 & 745.67 & 945 & $\begin{array}{l}78.9 \\
1\end{array}$ \\
\hline Inspiration & 2.166 & 722.00 & 945 & $\begin{array}{l}76.4 \\
0\end{array}$ \\
\hline Memorable & 2.248 & 749.33 & 945 & $\begin{array}{l}79.2 \\
9\end{array}$ \\
\hline Persuasion & 1.477 & 738.50 & 945 & $\begin{array}{l}78.1 \\
5\end{array}$ \\
\hline Total & $\mathbf{1 1 . 6 9 1}$ & $\mathbf{3 , 6 6 8 . 1 0}$ & $\mathbf{4 . 7 2 5}$ & $\begin{array}{l}\mathbf{7 7 . 6} \\
\mathbf{-}\end{array}$ \\
\hline
\end{tabular}

Source: Data Processing Result, 2018

The results showed that the highest dimension was memorable. This is in accordance with previous research which suggested that positive brand experience tends to be imprinted on the customer's mind. This can be produced by building consumer memories; specifically by identifying what attracted them (Pranadata, Rahayu, \& Hussein, 2017).

Based on the results of data processing, brand storytelling on the wedding marketplace website visitors can be measured through its dimension score. The total brand storytelling score is 11.691 while the ideal score is 15.120 . This comparison showed that brand storytelling on wedding marketplace websites had been well implemented. Ideally, the expected score from wedding marketplace website visitor responses to questions number 1 to 16 is 15.120 .

Published By:

Blue Eyes Intelligence Engineering

$\&$ Sciences Publication 
Figure 3 shows the observed value is 11.691 or $77.3 \%$ of the ideal score of 15,120 . Thus, brand storytelling was classified in "good" category. This can be seen from the results of data processing illustrating that the total score for brand storytelling is 11.691 . The total score is illustrated in the following continuum line:

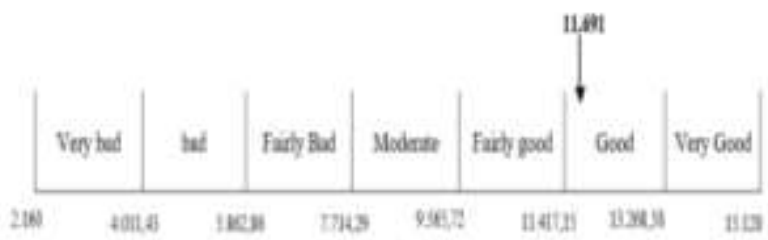

Fig. 3, Continuum Line of Brand Experience Variable

The result indicated that the wedding marketplace; the creation of brand storytelling has shown the expected performance even though this has yet to reach its peaks potential, given the importance of brand storytelling in supporting consumers' positive behavior.

\section{CONCLUSION}

The description of storytelling in the wedding marketplace can be seen from its dimensions which consist of a well-defined, recognizable, inspiration, influence, persuasion, memorable, compelling persona in a fairly high category. This indicated that the storytelling activities according to members of the Facebook Fanpage community were quite good. Overall, brand storytelling in wedding marketplaces can be categorized as good, but it needs to be improved specifically in terms of influence dimension. The influence of the information given by the company has the lowest value of influence because the story must be well defined, specific, and purposive because it will affect the audience decision to read the story. This is supposed to be done so that the audience will be interested in taking the first steps in responding to the storytelling activities carried out by the wedding marketplace.

\section{REFERENCES}

1. Flórez-Aristizábal L, Cano S, Collazos CA, Benavides F, Moreira F, Fardoun HM. Digital transformation to support literacy teaching to deaf Children: From storytelling to digital interactive storytelling. Telemat Informatics [Internet]. 2019;38:87-99. Available from: https://doi.org/10.1016/j.tele.2018.09.002

2. Hamdani NA. Building knowledge-creation for making business competition atmosphere in SMEs of Batik. Manag Sci Lett. 2018;8:667-76.

3. Ambrosius GR. Brand matters in an aging marketplace. J Act Aging. 2010;28-35.

4. Ryu K, Lehto XY, Gordon SE, Fu X. Compelling brand storytelling for luxury hotels. Int J Hosp Manag [Internet]. 2018;74(October 2017):229.Availablefrom:https://doi.org/10.1016/j.ijhm.2018.02.0 02

5. Smith K, Wintrob M. Brand Storytelling: A Framework for Activation. 2013;

6. Papadatos C. The art of storytelling: How loyalty marketers can build emotional connections to their brands. J Consum Mark. 2006;23(7):382-4.

7. Kim H-J, Park S-Y, Park H-Y. A Study on the Effect of Storytelling Marketing on Brand Image and Brand Attitude. Int Converg Manag Assoc. 2019;6(4):1-16.
8. Delgado-Ballester E, Fernández-Sabiote E. "Once upon a brand”: Storytelling practices by Spanish brands. Spanish J Mark - ESIC [Internet]. 2016;20(2):115-31. Available from: http://dx.doi.org/10.1016/j.sjme.2016.06.001

9. Muniz KM, Woodside AG, Sood S. Consumer storytelling of brand archetypal enactments. Int J Tour Anthropol. 2015;4(1):67.

10. Blakely K. Busy Brides and the Business of Family Life. J Fam Issues. 2007;29(5):639-62.

11. Lund NF, Cohen SA, Scarles C. The power of social media storytelling in destination branding. J Destin Mark Manag [Internet]. 2018;8(January):271-80. Available from: http://dx.doi.org/10.1016/j.jdmm.2017.05.003

12. Setyorini T. Bridestory Rilis Laporan Tren Pernikahan 2017 di Indonesia. www.merdeka.com. 2017;

13. Similiarweb.com. Website Analysis Weddingku, Bridestory, Rumahtaaruf, DatangYa! dan The Bride Dept. Similiarweb.com. 2017.

14. Nabila M. Strategi Bridestory Kuasai Pangsa Pasar “ Online Wedding Marketplace " di Asia Tenggara. Dailysocial.id. 2017.

15. Morgan-Thomas A, Veloutsou C. Beyond Technology Acceptance: Brand Relationships and Online Brand Experience. J Bus Res. 2013;66(1):21-7.

16. Keller KL. Strategic Brand Management. 4e ed. Pearson. England: Pearson Education Inc.; 2013.

17. Hamdani NA, Susanto T, Abdul Fatah Maulani G. Framework of Architectural Marketing Capabilities in Regional Development Bank. Int J Eng Technol [Internet]. 2018;7(3.25):166-9. Available from: https://www.sciencepubco.com/index.php/ijet/article/vie w/17539

18. Heding T, Knudtzen CF, Bjerre M. Brand Management: Reasearch, Theory and Practice. New York: Rou; 2015.

19. Alam Hamdani N, Abdul Fatah Maulani G. The influence of E-WOM on purchase intentions in local culinary business sector. Int J Eng Technol. 2018;7(2.29):246.

20. Pranadata IGP, Rahayu M, Hussein AS. Analisis Pengaruh Brand Experience Terhadap Brand Perceived Value, Brand Satisfaction dan Brand Loyalty (Studi Kasus pada Industri One Stop Carcare Service di Kota Malang). J Bisnis dan Manaj. 2017;4(2):217-27. 